\title{
Prenatal exome sequencing and chromosomal microarray analysis in fetal structural anomalies in a highly consanguineous population reveals a propensity of ciliopathy genes causing multisystem phenotypes
}

\author{
Mohamed Al-Hamed ( $\sim$ Hamed@kfshrc.edu.sa ) \\ King Faisal Specialist Hospital and Research Center https://orcid.org/0000-0002-7207-6122 \\ Wesam Kurdi \\ KFSHRC: King Faisal Specialist Hospital and Research Center \\ Rubina Khan \\ KFSH\&RC: King Faisal Specialist Hospital and Research Center
}

Maha Tulbah

KFSH\&RC: King Faisal Specialist Hospital and Research Center

Maha AlNemer

KFSH\&RC: King Faisal Specialist Hospital and Research Center

Nada AlSahan

KFSH\&RC: King Faisal Specialist Hospital and Research Center

Maisoon AlMugbel

KFSH\&RC: King Faisal Specialist Hospital and Research Center

Rafiullah Rafiullah

KFSH\&RC: King Faisal Specialist Hospital and Research Center

Mirna Assoum

KFSH\&RC: King Faisal Specialist Hospital and Research Center

Zuhair Rahbeeni

KFSH\&RC: King Faisal Specialist Hospital and Research Center

Nada Derar

KFSH\&RC: King Faisal Specialist Hospital and Research Center

Fahad Hakami

King Abdulaziz Medical City - Jeddah

\section{Gawaher Almutairi}

KFSH\&RC: King Faisal Specialist Hospital and Research Center

Afaf AlOtaibi

KFSH\&RC: King Faisal Specialist Hospital and Research Center

Wafaa Ali

KFSH\&RC: King Faisal Specialist Hospital and Research Center

Amal AlShammasi

KFSH\&RC: King Faisal Specialist Hospital and Research Center

Wardah AlMubarak

KFSH\&RC: King Faisal Specialist Hospital and Research Center

Samia AlDawoud

KFSH\&RC: King Faisal Specialist Hospital and Research Center

Saja AlAmri

KFSH\&RC: King Faisal Specialist Hospital and Research Center

Bashayer Saeed

KFSH\&RC: King Faisal Specialist Hospital and Research Center

Hanifa Bukhari

KFSH\&RC: King Faisal Specialist Hospital and Research Center

Mohannad Ali 
KFSH\&RC: King Faisal Specialist Hospital and Research Center

\section{Rana Akili}

KFSH\&RC: King Faisal Specialist Hospital and Research Center

Laila Alquayt

KFSH\&RC: King Faisal Specialist Hospital and Research Center

Hadeel Elbardisy

King Abdulaziz City for Science And Technology

Asma Akilan

SDL

Nora Almuhana

SDL

\section{Abrar AlKhalifah}

SDL

Khushnooda Ramzan

KFSH\&RC: King Faisal Specialist Hospital and Research Center

John A. Sayer

Newcastle University Institute of Genetic Medicine

Faiqa Imtiaz

KFSH\&RC: King Faisal Specialist Hospital and Research Center

\section{Research Article}

Keywords: fetal anomalies, prenatal exome, consanguineous families, diagnostic yield, trio-ES, multisystem anomalies

Posted Date: August 25th, 2021

DOI: https://doi.org/10.21203/rs.3.rs-828519/v1

License: (c) (i) This work is licensed under a Creative Commons Attribution 4.0 International License. Read Full License

Version of Record: A version of this preprint was published at Human Genetics on December 1st, 2021. See the published version at https://doi.org/10.1007/s00439-021-02406-9. 


\section{Abstract Background}

Fetal abnormalities are detected in 3\% of all pregnancies and are responsible for approximately $20 \%$ of all perinatal deaths. Chromosomal microarray analysis (CMA) and exome sequencing (ES) are widely used in prenatal settings for molecular genetic diagnostics with variable diagnostic yields. In this study, we aimed to determine the diagnostic yield of trio-ES in detecting the cause of fetal abnormalities within a highly consanguineous population.

\section{Methods}

In families with a history of congenital anomalies, a total of 119 fetuses with structural anomalies were recruited and DNA from invasive samples were used together with parental DNA samples for trio-ES and CMA. Data were analysed to determine possible underlying genetic disorders associated with observed fetal phenotypes.

\section{Results}

The cohort had a known consanguinity of $81 \%$. Trio-ES led to diagnostic molecular genetic findings in 59 fetuses (with pathogenic / likely pathogenic variants) most with multisystem or renal abnormalities. CMA detected chromosomal abnormalities compatible with the fetal phenotype in another 7 cases. Monogenic ciliopathy disorders with an autosomal recessive inheritance were the predominant cause of multisystem fetal anomalies (24/59 cases, 40.7\%) with loss of function variants representing the vast majority of molecular genetic abnormalities. Heterozygous de novo pathogenic variants were found in 4 fetuses. A total of 23 novel variants predicted to be associated with the phenotype were detected.

\section{Conclusion}

Prenatal trio-ES and CMA detected likely causative molecular genetic defects in a total of $55 \%$ of families with fetal anomalies confirming the diagnostic utility of trio-ES and CMA as first line genetic test in the prenatal diagnosis of multisystem fetal anomalies including ciliopathy syndromes.

\section{Introduction}

Fetal abnormalities are present in $3 \%$ of all pregnancies and are responsible for around $20 \%$ of all perinatal deaths (Vora and Hui 2018 ). Prenatal ultrasound scanning (USS) of the fetus may be used to detect a range of anomalies, from a single minor defect to a severe multisystem disorder (Lord et al. 2019). Chromosomal abnormalities, inherited and de novo genetic disorders and multifactorial conditions are well known to be major contributors to birth defects, although the aetiology of many congenital malformations remains unknown (Yates et al. 2017). Genetic diagnosis of fetal structural anomalies is an important step in the evaluation and clinical management of the fetus and managing the family's expectations. Fetal anomalies can be associated with all types of chromosomal and genetic abnormalities that include aneuploidy, copy number variations (CNVs) and gene-specific pathogenic variants (Lord et al. 2019). For many years, prenatal diagnosis was performed by fetal USS followed by conventional karyotype and/or chromosomal microarray analysis (CMA) using amniotic fluid, chorionic villus sampling or DNA extracted from cord blood. The addition of CMA in prenatal diagnosis increases the frequency of diagnosis of chromosomal abnormalities by 3-5\% (Wapner et al. 2012). More recently, exome sequencing (ES) and genome sequencing (GS) have been applied to fetal molecular genetic diagnostics in order to improve diagnostic yield (Best et al. 2018; Talkowski et al. 2012). Recently, massive-parallel sequencing (also known as next generation sequencing (NGS)) based CNV detection has also been used as a diagnostic method for the detection of fetal chromosome anomalies (Wang et al. 2018) and the discovery of circulating cell-free fetal DNA (cffDNA) in maternal plasma has opened up a new approach for non-invasive prenatal screening (NIPD)(Rafi and Chitty 2009). ES is becoming the first line molecular test for a huge range of genetic disorders and there is some evidence that it has improved the detection rate of prenatal diagnosis (Best et al. 2018). Prenatal genetic diagnosis using ES varies between 10 and 57\% (Vora et al. 2017), and this huge range maybe attributed to variables in inclusion criteria, family history of prenatal anomalies, fetal USS abnormalities, trio (an affected proband with both parents) versus solo ES and may other technical factors.

Recently, a large study, which included ES in 610 fetuses with structural anomalies detected by fetal USS resulted in a diagnostic yield of $12.4 \%$, including variants of unknown significance (Lord et al. 2019) while another similar-sized investigation resulted in a detection rate of $10 \%$ (Petrovski et al. 2019). The efficiency of trio-ES over solo-ES is widely accepted and the implementation of trio-ES in prenatal diagnosis leads to a higher detection rate (Dillon et al. 2018; Jelin and Vora 2018). 
The Saudi Arabian population has a consanguinity rate of more than $50 \%$ and had a fertility rate of 2.3 births per woman in 2019 (Alkuraya 2013). In prenatal hospital settings with the aid of fetal USS, the detection rate of genetic causes of underlying anomalies using ES is expected to be higher than previously reported, especially in a consanguineous population such as Saudi Arabia. Although many studies worldwide describe the diagnostic yield of ES in prenatal settings, no previous reports have studied prenatal cases from consanguineous couples using ES This study demonstrates the diagnostic yield of trio-ES combined with CMA in fetuses with ultrasound structural anomalies in a highly consanguineous population and reveals a high rate of variants in ciliopathy syndrome genes accounting for multisystem fetal anomalies.

\section{Material And Methods}

\subsection{Study cohort}

A total of 119 fetuses from 119 not knowingly related families were recruited at the Maternal Fetal Medicine section of King Faisal Specialist Hospital and Research Centre in Riyadh, Saudi Arabia from November 2018 until January 2020. Inclusion criteria included pregnant women with a family history of congenital anomalies (defined as at least one previous fetus / child from the same family having congenital anomalies) and acceptance of invasive testing for identified structural anomalies or nuchal translucency in their fetus as detected by USS after 12 weeks of gestation. The parents, following informed written consent, participated in blood testing for DNA extraction and molecular genetic analysis. All families of fetuses with structural anomalies detected by antenatal USS were recruited for clinical service diagnosis by trio-ES and CMA testing according to the American College of Obstetricians \& Gynecologists (ACOG) guidelines (American College of et al. 2016). Fetal DNA was extracted from either chorionic villi, amniotic fluid, or cord blood. The study was conducted according to the Declaration of Helsinki and approved by the local institutional review board (IRB) (KFSHRC RAC\# 2211035).

\subsection{Prenatal USS examination, DNA extraction \& Maternal cell contamination (MCC)}

Prenatal anatomy USS examination was performed for all families labelled as a "high-risk pregnancy." For cases with a known family history of fetal anomalies, serial prenatal USS examinations started between 12 and 34 weeks gestation. For new referrals and unknown family history, prenatal USS started at the first antenatal visit. Fetal anatomy was reported as either normal or abnormal with explanations for features as previously described (Al-Hamed et al. 2016). Fetal death (FD) was defined as an intrauterine death after 10 gestational weeks, perinatal death (PD) within seven days of birth and infant death (ID) within one year of birth.

DNA was extracted using the Gentra Systems PUREGENE DNA Isolation kit (Qiagen, USA). Maternal cell contamination (MCC) was excluded in all fetal samples using the AmpFLSTR ${ }^{\circledR}$ Identifiler ${ }^{\circledR}$ PCR Amplification Kit as described by the manufacturer (Applied Biosystems, Life Technologies).

\subsection{Trio-ES and Variant Interpretation}

Trio-ES was performed on fetal and parental genomic DNA using an Agilent Sureselect All Exons V5 (50 Mb) capture kit (Agilent Technologies; Santa Clara, CA, USA) as described previously (Monies et al. 2017). An in-house variant interpretation pipeline was used for variant interpretation as previously described (Monies et al. 2017). We used the ACMG guidelines based websites Franklin by Gennox (https://franklin.genoox.com) and VarSome (Kopanos et al. 2019) (https://varsome.com) for variant interpretation. The variant classification of trio-ES results was based on ACMG guidelines and categorized into four groups:

(A): Pathogenic or Likely Pathogenic (P/LP) explaining the phenotype: all reported pathogenic variants and novel (not reported) loss of function variants in a gene where loss of function is a known mechanism of disease according to ACMG guidelines, (B): Variants of unknown significance (VUS) that explain the phenotype: all extremely low frequency missense and intronic variants with uncertain significance in genes causing the phenotype, (C): Negative: where no potential variants were identified to describe the disease phenotype, and (D): Cases with chromosomal abnormalities solved by CMA.

HGMD $®$ Professional 2020.2 database was used as a reference for the previously reported variants. In addition to Online Mendelian Inheritance in Man (OMIM), the Genomics England PanelApp (https://panelapp.genomicsengland.co.uk/) was used to assess the genotype-phenotype correlation

\subsection{Sanger sequencing}

Sanger sequencing validation was performed for all de novo, novel and low quality metric variants (depth of coverage, base quality and mapping quality). Oligonucleotide primers for PCR amplification of targeted variants were designed using Primer3 software (http://frodo.wi.mit.edu/) and synthesized in house. The amplified PCR products were sequenced using an ABI 3730xl capillary sequencer (Applied Biosystems, CA, USA) and sequences were analysed using Mutation Surveyor software V.3.24 (SoftGenetics LLC, State College, Pennsylvania, USA).

\subsection{Chromosomal Microarray Analysis (CMA)}


CMA was performed in cases with a suspicion of chromosomal abnormalities. This includes advanced maternal age (above 35 years), the first abnormal fetus with no other family history and a non-consanguineous couple. CMA was also performed for all cases with a negative trio-ES analysis except for five fetuses due to insufficient quantities of DNA. Genomic DNA was fragmented, amplified and hybridized to the array according to manufacturer's guidelines (Affymetrix CytoScan® HD Array Kit). It contains 2.7 million markers across the genome covering $96 \%$ of the genes. Results were analysed with the Chromosome Analysis suite (ChAS, Affymetrix). Copy number variations (CNVs) with more than 50 kb (deletions) and $200 \mathrm{~kb}$ (duplications) are reported. CMA was performed on 67 cases out of 119 fetuses who met the above criteria. Classification of CNVs was based on the ACMG standards and guidelines for interpretation and reporting of constitutional CNVs (Riggs et al. 2020). CNVs were evaluated in terms of their pathogenicity and contribution to the fetal phenotype.

\section{Results}

A total of 119 fetuses from 119 Saudi Arabian families were investigated in this study by trio-ES analysis (Table 1). Sixty-seven fetuses were investigated by CMA in addition to trio-ES. Ninety-seven of the 119 enrolled families (81\%) were known to be consanguineous. The average gestational age for prenatal testing was 26 weeks. Trio-ES with an average turn-around time of 31 days detected 59 cases (49\%) with a confirmed diagnosis in Group A with pathogenic or likely pathogenic alleles (Table 2, Fig. 1) and 21 (18\%) in Group-B with variants of unknown significance that were in genes that likely explained the phenotype (Table 3). Trio-ES was negative in 32 (27\%) cases. Seven cases had positive CMA results that were thought to be diagnostic of the fetal anomalies present (Table 4).

Table 1

Summary of genetic diagnostic data of the fetal anomalies study cohort

\begin{tabular}{|ll|}
\hline Findings & No. of cases \\
\hline Total number of cases & 119 \\
\hline Known consanguineous families & $97(81 \%)$ \\
\hline Cases with a diagnostic class A (P/LP) variant & $59(49 \%)$ \\
\hline Cases with class B (VUS) variant (that may explain phenotype) & $21(18 \%)$ \\
\hline Cases with class C (Negative ES and CMA) & $32(27 \%)$ \\
\hline Cases with class D (positive CMA findings that explains phenotype) & $7(6 \%)$ \\
\hline
\end{tabular}


Table 4

Fetal anomaly cases with positive chromosomal microarray analysis (CMA) findings

\begin{tabular}{|c|c|c|c|c|c|c|}
\hline Family & Outcome & $\begin{array}{l}\text { Maternal } \\
\text { age }\end{array}$ & Consanguinity & CMA results & Exome sequencing results & $\begin{array}{l}\text { Fetal } \\
\text { structural } \\
\text { defects }\end{array}$ \\
\hline FAM-4 & PD & 43 & No & Trisomy 18 (Pathogenic) & Negative & Multisystem \\
\hline $\begin{array}{l}\text { FAM- } \\
43\end{array}$ & Livebirth & 20 & No & $\begin{array}{l}\text { Distal Trisomy 14q syndrome } \\
\text { (Pathogenic) }\end{array}$ & Negative & Multisystem \\
\hline $\begin{array}{l}\text { FAM- } \\
45\end{array}$ & PD & 22 & Yes & $\begin{array}{l}10 q 11 \text { microduplication (Pathogenic, } \\
\text { but unlikely to contribute to } \\
\text { antenatal phenotype) }\end{array}$ & $\begin{array}{l}\text { DIS3L2:NM_152383.5:c.1810C } \\
\text { > T; p.GIn604* (Homozygous) }\end{array}$ & Renal \\
\hline $\begin{array}{l}\text { FAM- } \\
67\end{array}$ & PD & 32 & No & Trisomy 18 (Pathogenic) & Negative & Multisystem \\
\hline $\begin{array}{l}\text { FAM- } \\
78\end{array}$ & ID & 33 & Yes & Mosaic Trisomy 15 (Pathogenic) & Negative & Multisystem \\
\hline $\begin{array}{l}\text { FAM- } \\
79\end{array}$ & ID & 27 & Yes & $\begin{array}{l}\text { Male fetus with duplication of short } \\
\text { arm of X chromosome, Xp11.4 (VUS) }\end{array}$ & Negative & $\begin{array}{l}\text { Central } \\
\text { nervous }\end{array}$ \\
\hline $\begin{array}{l}\text { FAM- } \\
89\end{array}$ & PD & 28 & Yes & $\begin{array}{l}\text { Isochromosome 12p (Pallister-Killian } \\
\text { syndrome) (Pathogenic) }\end{array}$ & $\begin{array}{l}\text { MASP1: } \\
\text { NM_139125.4:c.1358G > A; } \\
\text { p.Gly453Asp (Homozygous, } \\
\text { VUS) }\end{array}$ & Multisystem \\
\hline $\begin{array}{l}\text { FAM- } \\
93\end{array}$ & FD & 25 & Yes & Turner syndrome $(45, \mathrm{X})$ (Pathogenic) & Negative & Multisystem \\
\hline $\begin{array}{l}\text { FAM- } \\
105\end{array}$ & FD & 26 & Yes & Turner syndrome $(45, X)$ (Pathogenic) & Negative & $\begin{array}{l}\text { Fetal } \\
\text { hydrops }\end{array}$ \\
\hline
\end{tabular}

The phenotypic spectrum of fetuses varied in severity, most likely due to the underlying genes and variant type (Table S1). The majority of fetuses had severe multisystem phenotypes, hydrops fetalis, brain abnormalities or renal anomalies. Fetal death, perinatal death, infant death and termination of pregnancy represent the vast majority of pregnancy outcomes in the study (Fig. 2).

The majority of cases were solved by pathogenic variants in known ciliopathy genes with autosomal recessive inheritance pattern. Pathogenic (homozygous) variants of NPHP3 were found in 5 fetuses, with 4 of them (FAM-60, FAM-63, FAM-100, FAM-104) sharing the same homozygous allele c.2694-2_2694-1delAG suggesting that these families are interrelated. Similarly, in CC2D2A pathogenic (homozygous) variants were found in 4 fetuses with severe multisystem phenotypes including encephalocele, 3 of whom had the identical allele c.3084delG again suggesting these families may all be founder related. Pathogenic biallelic variants were also detected in more than one case for the known ciliopathy genes PKHD1 and TMEM94. A shared and known pathogenic allele in CTU2 (c.873G > A; p. Thr291Thr) (Shaheen et al. 2019) was identified in 3 cases with multiple anomalies including brain and renal phenotypes and corresponds to a likely founder allele in the Saudi Arabian population.

A total of 16 novel pathogenic variants and 7 novel VUS were detected in 22 different genes (Figure S1). Novel variants included missense, frameshift, nonsense and splicing defects and correlated closely with the phenotypes observed. Most variants detected were loss of function and they were often lethal, causing fetal or perinatal death.

\subsection{Group A: Pathogenic or likely pathogenic variants explaining the phenotype}

59 fetuses were identified with pathogenic or likely pathogenic variants explaining the phenotype (Table 2). 4 heterozygous de novo variants were detected in four fetuses. The de novo variant (MYH3:c.2501T > C; p.Phe834Ser) was novel (Figure S1) whilst the other 3 variants in PTPN11, FGFR3, and FOXF1 have been reported previously (Abu-El-Haija et al. 2018; Rump et al. 2006; Stankiewicz et al. 2009; Tartaglia et al. 2004; Toydemir et al. 2006).

54 homozygous variants and one compound heterozygous loss of function variants were detected in this group, 16 of them were novel. In FAM45 trio-ES detected a loss of function variant (DIS3L2:c.1810C > T; p.GIn604*) on chromosome 2q37.1 and CMA detected a 10q11 microduplication. The variant in DIS3L2 is associated with Perlman syndrome, which is consistent with prenatal USS findings in this fetus, showing fetal ascites and enlarged kidneys. The $10 \mathrm{q}$ microduplication is a well-defined and rare genetic occurrence that may lead to severe central hypotonia, mild ataxia, moderate developmental delay and mild dysmorphic features that would be unlikely to be detected antenatally (Manolakos et al. 2014). 
Along with the abnormal USS findings, the molecular genetic findings in this study may support the pathogenicity of the following genes: $A G R N$ (Geremek et al. 2020), MPDZ (Saugier-Veber et al. 2017), IL6ST (Schwerd et al. 2017), TBC1D32 (Alsahan and Alkuraya 2020), CANT1 (Laccone et al. 2011), FZD6 (Shamseldin et al. 2015) and TMEM94 (Al-Hamed et al. 2020) as etiologies of fetal structural anomalies.

Our data also supports previous findings of an association of biallelic NEK8 mutations with a multisystem ciliopathy phenotype (Al-Hamed et al. 2016; Frank et al. 2013). The fetus FAM-53, with a homozygous nonsense mutation in NEK8 had multisystem features consistent with a ciliopathy syndrome which included hypoplastic lung, Dandy-Walker malformation and enlarged cystic-dysplastic kidneys.

There were several instances where the phenotype we report extends the clinical disease spectrum associated with a known gene alterations. The pathogenic variant c.830-1G $>\mathrm{A}$ in $/ G F B P 7$ gene has previously been associated with retinal arterial macroaneurysm with supravalvular pulmonic stenosis (Abu-Safieh et al. 2011). In this study, we observed a hypoplastic right heart in the fetus (FAM-55) with a pathogenic IGFBP7 variant. In FAM-16 where fetal USS indicated bilateral renal agenesis and pericardial effusion, we detected a homozygous loss of function variant of $C D 151$ (NM_001039490.2: c.493C > T; p.Arg165*). Defects in CD151 have been associated with nephropathy with pretibial epidermolysis bullosa and deafness (Vahidnezhad et al. 2018). CD151 encodes a cell surface glycoprotein that is involved in cellular processes, including cell adhesion and it may regulate integrin trafficking and/or function. Importantly, an 11 year old sibling of FAM-16 was also homozygous for the CD151 variant and has a severe nephropathy leading to end stage kidney disease requiring renal transplantation, implicating this gene is early onset renal phenotypes that may include congenital anomalies. The fetus FAM-2 presented with a severe congenital anomalies of the kidney and urinary tract phenotype rather than the more typical alveolar capillary dysplasia with misalignment of pulmonary veins. Genitourinary findings have however been previously associated with heterozygous nonsense and frameshift mutations in FOXF1 as well as microdeletions in 16q24.1q24.2 affecting the FOX gene cluster (FOXF1, FOXC2, FOXL1) (Stankiewicz et al. 2009). Mutations in $B L M$ are typically associated with Bloom syndrome, a rare genodermatosis disorder characterised by genomic instability and cancer predisposition (Hafsi et al. 2021). A prenatal growth deficiency is a prominent feature but the skeletal features noted in in FAM-69 (absent left radius, absent left thumb and syndactyly of hand) are atypical. Biallelic mutations in POMT1 result in a dystroglycanopathy (Walker-Warburg syndrome) resulting in congenital muscular dystrophy with brain and eye involvement. Genital hypoplasia has also been reported (Beltrán-Valero de Bernabé et al. 2002). FAM-112 had features of brain, heart and kidney involvement. Interestingly, POMT2 mutations have also been associated with cystic kidneys expanding that known disease spectrum for this group of disorders (Nabhan et al. 2017).

\subsection{Group B: VUS explaining the phenotype}

Twenty-one fetal anomaly cases were identified with VUS likely explaining the phenotype (Table 3). The phenotypes included 4 fetuses with hydrops fetalis, 9 with multisystem anomalies, 4 with renal and 4 with skeletal anomalies. A total of twenty-three VUS were identified (some patients having more than one VUS) of which 7 variants were novel. All detected variants were biallelic except for 2 cases where monoallelic variants were detected in HOXD13 and SALL1 in non-consanguineous families (FAM-39 and FAM-51) with skeletal dysplasia and multicystic kidneys, respectively. Pathogenic alleles in both these genes which encode developmentally important transcription factors, cause similar phenotypes to the patients we describe.

In FAM-28, a missense change in CEP290 (c.4151G > A; p.Arg1384His) was noted in a fetus with a multisystem ciliopathy-like phenotype. There is a reported pathogenic variant (c.4150C > T; p.Arg1384Cys) which affects the identical amino acid position, providing moderate evidence of pathogenicity of the variant p.Arg1384His according to ACMG guidelines (PM5). In addition, we identified a presumed loss of function variant of $A C D$ in FAM-57 whom demonstrated non-immune hydrops fetalis (NIHF), polyhydramnios, and hypertrophied cardiac muscle. Defects in $A C D$ are typically associated with dyskeratosis congenita. Although no previous association between NIHF and defects in $A C D$ gene have been reported, we postulate that the severe form of bone marrow failure could explain this phenotype.

We identified a novel homozygous variant in UPK3A gene (UPK3A:NM_006953:exon2:c.53-1G > A) in a fetus that displayed anhydramnios, bilateral echogenic kidneys and cardiomegaly. Compound heterozygous variants in UPK3A have been associated with congenital nephrotic syndrome (Liu et al. 2019) as well as congenital anomalies of the kidney and urogenital tract.

\subsection{Group C: Negative Trio-ES cases}

There were 32 cases (27\%) where trio-ES was unable to detect molecular cause of fetal abnormalities with a wide range of structural phenotypes. CMA was performed on 27 of these 32 cases and a likely molecular genetic cause for the underlying phenotype was found in 7 cases (detailed below). For the remaining 5 cases CMA testing was not performed due to insufficient DNA. Unsolved cases were a broad mixture of phenotypes including NIHF, cystic kidney disease, multisystem disorders and central nervous system disorders (Fig. 2, Table S1).

\subsection{Group D: Positive CMA cases}

9 fetal cases had a genetic abnormality identified by CMA, of which 8 were likely to be pathogenic and 7 were likely to be associated with the presenting antenatal phenotype. Seven cases were initially negative for trio-ES and genetic defects were identified using CMA. A single case (FAM-89) had a VUS identified in addition to CMA findings whilst FAM-45 was positive for genetic abnormalities trio-ES in addition to a CMA

Page $7 / 18$ 
variant (10q11 microduplication) associated with postnatal rather than prenatal phenotypes. The chromosomal abnormalities detected were all are of known pathogenicity and included Trisomy 18, Trisomy 14q syndrome, Trisomy 15 and Turner syndrome (Table S1), except for one case (FAM-79) where the CMA finding (a duplication of a region on the short arm of chromosome X (Xp11.4)) is of uncertain significance in a male fetus with an encephalocele.

\subsection{Families with more than one variant}

In a consanguineous population, pathogenic variants in more than one gene can be expected in a family (AIAbdi et al. 2021). These findings are very important for prevention and establishing appropriate prenatal management for future pregnancies. Five fetuses (4.7\%) were identified to have more than one potentially disease causing genetic diagnosis.

FAM-45 had both a positive ES result (DIS3L2 nonsense variant, associated with Perlman syndrome that corresponds to the fetal USS findings of echogenic kidneys and moderate ascites) and pathogenic CMA findings (10q11 microduplication) which is a known mechanism in patients with neurological abnormalities (Stankiewicz et al. 2012). FAM-89 had a positive CMA result (Isochromsome 12p, consistent with the genetic diagnosis of Pallister-Killian syndrome) combined with a VUS in MASP1 which is associated with 3MC syndrome. Both defects could have pathogenic implications for the fetal phenotype (Lawson et al. 2020; Salzano et al. 2018).

FMA-99 had 2 pathogenic missense alleles in $D Y N C 2 H 1$ and $A R S B$; that would be predicted to contribute to the phenotype of skeletal dysplasia whilst FAM-9 and FAM-115 both had 2 homozygous VUS alleles. FAM-9 showed bilateral enlarged kidneys with anhydramnios. Two homozygous VUS, c.105G > A; p.Met35Ile in CILK1 (ICK gene) and c.2180A > G; p.Asn727Ser in PKHD1 were detected. Both missense variants shared the same block of homozygosity in the short $(p)$ arm of chromosome 6 and both could explain the echogenic kidney phenotype. The c.2180A > G; p.Asn727Ser variant in PKHD1 has been reported previously, but according to HGMD and ClinVar with uncertain significance (Wojcik et al. 2019). However, the CILK1 variant is novel and according to ACMG guidelines, should be classified as a VUS.

In FAM-115 fetal USS indicated multisystem abnormalities and both VUS variants TUBA8: c.958C > T; p.Arg320Trp and LZTR1: c.1055A > C; p.Tyr352Ser could participate in the complex fetal phenotype.

\subsection{Postnatal Fetal Phenotypes}

At least 22 cases (18.5\%) of our cohort were liveborn and survived the perinatal period, indicating the high disease severity of the cohort. 11 had class A variants, 2 with class B variants and one with class-D chromosomal abnormality. Clinical phenotypes in genetically solved cases surviving the perinatal period were re-assessed postnatally (Table 5). Postnatal phenotypes confirmed fetal USS findings and showed good concordance, with patients exhibiting expected phenotypes consistent with their molecular diagnosis. 
Table 5

Postnatal fetal phenotype of livebirth cases with detected trio-ES variants.

\begin{tabular}{|c|c|c|c|c|c|c|c|}
\hline FAM\# & $\begin{array}{l}\text { Age } \\
\text { (months) }\end{array}$ & Gender & Mutation & Zygosity & CMA & Fetus Phenotype & $\begin{array}{l}\text { Postnatal Fetal } \\
\text { Phenotype }\end{array}$ \\
\hline $\begin{array}{l}\text { FAM- } \\
5\end{array}$ & 20 & Female & $\begin{array}{l}\text { ASPM } \\
(\text { NM_001206846.1):c.1959_1962delCAAA } \\
\text { (p.Asn653Lysfs*14) }\end{array}$ & $\begin{array}{l}\text { Hom / } \\
\text { AR }\end{array}$ & Negative & Microcephaly & Microcephaly \\
\hline $\begin{array}{l}\text { FAM- } \\
14\end{array}$ & 21 & Male & $\begin{array}{l}\text { MYH3 (NM_002470.4):c.2501T > C } \\
\text { (p.Phe834Ser) }\end{array}$ & $\begin{array}{l}\text { Het, de } \\
\text { novo }\end{array}$ & $\mathrm{N} / \mathrm{P}$ & $\begin{array}{l}\text { Kyphosis, cleft } \\
\text { foot/toes, wrist } \\
\text { abnormalities, } \\
\text { both elbows } \\
\text { fixed, flexed joint, } \\
\text { abnormal nose }\end{array}$ & $\begin{array}{l}\text { Bilateral club } \\
\text { foot, hip flexion, } \\
\text { deformity of both } \\
\text { knees and } \\
\text { deformity of } \\
\text { upper limbs }\end{array}$ \\
\hline $\begin{array}{l}\text { FAM- } \\
33\end{array}$ & 26 & Female & $\begin{array}{l}\text { CPLANE1 } \\
\text { (NM_023073.3):c.7988_7989delGA } \\
\text { (p.Gly2663Alafs*40) }\end{array}$ & $\begin{array}{l}\text { Hom / } \\
\text { AR }\end{array}$ & $\mathrm{N} / \mathrm{P}$ & $\begin{array}{l}\text { Hydrocephalus, } \\
\text { Dandy-Walker } \\
\text { malformation }\end{array}$ & $\begin{array}{l}\text { Developmental } \\
\text { delay, } \\
\text { hydrocephalus }\end{array}$ \\
\hline $\begin{array}{l}\text { FAM- } \\
38\end{array}$ & 23 & Male & $\begin{array}{l}\text { MPDZ (NM_001261406.2):c.628C > T } \\
\text { (p.GIn210*) }\end{array}$ & $\begin{array}{l}\text { Hom / } \\
\text { AR }\end{array}$ & $\mathrm{N} / \mathrm{P}$ & $\begin{array}{l}\text { Absent corpus } \\
\text { callosum }\end{array}$ & $\begin{array}{l}\text { Congenital } \\
\text { hydrocephalus }\end{array}$ \\
\hline $\begin{array}{l}\text { FAM- } \\
40\end{array}$ & 22 & Male & $\begin{array}{l}\text { TBX18 } \\
\text { (NM_001080508.3):c.692_693insT } \\
\text { (p.Glu233Glyfs*19) }\end{array}$ & Het / AD & Negative & $\begin{array}{l}\text { Bilateral } \\
\text { hydronephrosis }\end{array}$ & $\begin{array}{l}\text { Bilateral } \\
\text { hydronephrosis }\end{array}$ \\
\hline $\begin{array}{l}\text { FAM- } \\
55\end{array}$ & 21 & Male & IGFBP7(NM_001553.3):c.830-1G > A & $\begin{array}{l}\text { Hom / } \\
\text { AR }\end{array}$ & Negative & $\begin{array}{l}\text { Hypoplastic right } \\
\text { heart }\end{array}$ & $\begin{array}{l}\text { Right ventricular } \\
\text { hypoplasia. }\end{array}$ \\
\hline $\begin{array}{l}\text { FAM- } \\
69\end{array}$ & 23 & Female & $\begin{array}{l}\text { BLM(NM_000057.4):c.175_176delGT } \\
\text { (p.Val59llefs*4) }\end{array}$ & $\begin{array}{l}\text { Hom / } \\
\text { AR }\end{array}$ & Negative & $\begin{array}{l}\text { Absent left } \\
\text { radius, absence } \\
\text { of left thumb, } \\
\text { syndactyly left } \\
\text { hand }\end{array}$ & $\begin{array}{l}\text { Oesophageal } \\
\text { atresia with } \\
\text { transoesophageal } \\
\text { fistula repaired, } \\
\text { imperforate anus, } \\
\text { absent thumb, } \\
\text { absent radius }\end{array}$ \\
\hline $\begin{array}{l}\text { FAM- } \\
88\end{array}$ & 18 & Male & $\begin{array}{l}\text { FZD6 (NM_003506.4):c.869A > G } \\
\text { (p.Tyr290Cys) \& }\end{array}$ & $\begin{array}{l}\text { Hom / } \\
\text { AR }\end{array}$ & $\mathrm{N} / \mathrm{P}$ & $\begin{array}{l}\text { Non-immune } \\
\text { hydrops fetalis }\end{array}$ & Asymptomatic \\
\hline $\begin{array}{l}\text { FAM- } \\
94\end{array}$ & 14 & Male & $\begin{array}{l}\text { THSD1 (NM_018676.4):c.617G >A } \\
\text { (p.Cys206Tyr) }\end{array}$ & $\begin{array}{l}\text { Hom / } \\
\text { AR }\end{array}$ & $\mathrm{N} / \mathrm{P}$ & $\begin{array}{l}\text { Non-immune } \\
\text { hydrops fetalis }\end{array}$ & Asymptomatic \\
\hline $\begin{array}{l}\text { FAM- } \\
15\end{array}$ & 24 & Female & $\begin{array}{l}\text { PIEZO1 (NM_001142864.4):c.1792G > A } \\
\text { (p.Val598Met) }\end{array}$ & $\begin{array}{l}\text { Het / } \\
\text { AR, AD }\end{array}$ & N/P & $\begin{array}{l}\text { Non-immune } \\
\text { hydrops fetalis }\end{array}$ & $\begin{array}{l}\text { Respiratory } \\
\text { difficulties }\end{array}$ \\
\hline $\begin{array}{l}\text { FAM- } \\
113\end{array}$ & 21 & Male & $\begin{array}{l}\text { TTC8 (NM_001288782.1):c.107G > A } \\
\text { (p.Cys36Tyr) }\end{array}$ & $\begin{array}{l}\text { Hom / } \\
\text { AR }\end{array}$ & $\mathrm{N} / \mathrm{P}$ & $\begin{array}{l}\text { Polydactyly, } \\
\text { Echogenic } \\
\text { kidney, } \\
\text { Oligohydramnios }\end{array}$ & $\begin{array}{l}\text { Bardet-Biedl } \\
\text { syndrome with } \\
\text { multiple } \\
\text { congenital } \\
\text { anomalies: } \\
\text { congenital heart } \\
\text { disease, Bilateral } \\
\text { polycystic kidney } \\
\text { with chronic } \\
\text { kidney disease } \\
\text { stage III, } \\
\text { ambiguous } \\
\text { genitalia with } \\
\text { undervirilized } \\
\text { male }\end{array}$ \\
\hline
\end{tabular}

\section{Discussion}

In this prenatal cohort of 119 fetuses affected with wide range of fetal structural anomalies, we detected a diagnostic (pathogenic/likely pathogenic) molecular genetic variant in $49 \%$ of fetuses. In addition, we identified a potentially clinically relevant variant which was classified by ACMG criteria as a VUS in 21 (18\%) fetuses. Previous large studies identified diagnostic genetic variants in 12.5\% (Lord et al. 2019) and $10 \%$ (Petrovski et al. 2019) of fetuses with fetal structural anomalies. The differences in diagnostic yields reflect the differences in study inclusion criteria where we recruited families with a history of fetal anomalies. Therefore, high diagnostic yield of our study can be attributed to the previously identified family history of fetal anomalies, consanguineous marriages often involving first cousins, and tribal structure of the Saudi Arabian population leading to several likely founder effect or shared pathogenic alleles. The overall diagnostic yield of our study is comparable to findings by Best et al (Best et al. 2018). What is very striking is the large number of recessive ciliopathy genes identified in our 
cohort. There is very little overlap with the previously reported UK cohort (Lord et al. 2019), where the leading diagnostic genetic causes of structural fetal anomalies included KMT2S, CHD7 and PTPN11 all inherited as autosomal dominant conditions. The only overlapping genetic causes between this study and the data presented here included FGFR3 (identification of heterozygous variants) and PIEZO1. We saw shared pathogenic alleles within ciliopathy genes NPHP3 and CC2D2A. NPHP3 is now the commonest genetic cause of infantile nephronophthisis (Chaki et al. 2011; Srivastava et al. 2017; Tory et al. 2009) and may also lead to severe antenatal phenotypes including Meckel syndrome (Bergmann et al. 2008). Pathogenic variants in CC2D2A are also associated with a spectrum of ciliopathy phenotypes which include Meckel syndrome (Tallila et al. 2008). All the fetuses with CC2D2A mutations in our cohort had encephalocoles and cystic kidney disease consistent with Meckel syndrome.

The shared allele in CTU2, c.873G>A (p.Thr291Thr) is apparently synonymous allele, but has been previously shown to cause loss of the wild type transcript and leads to a splicing defect leading to a frameshift and premature protein truncation (Shaheen et al. 2016b) and has been shown to be a founder mutation in Saudi Arabian patients (Shaheen et al. 2016a). Recognition of disease causing synonymous variants is important as these may be easily an inadvertently discarded by filtering steps in genetic pipelines (Olinger et al. 2021).

Fetal phenotypic evaluations are limited and largely dependent on imaging systems (Fetal USS or fetal MRI). Several factors impact fetal phenotyping such as imaging instrument, maternal body habitus, fetal position, and gestational age (Oates and Taylor 2016). 3D ultrasound is very valuable in the first trimester of pregnancy, but other instruments such as fetal MRI and echocardiography are useful in special cases. We were limited in evaluating postnatal phenotype of all born fetuses due to many factors that include the fact that our centre is a tertiary referral centre and that the majority of pregnancies resulted in termination, fetal death or perinatal death. The high rate for fetal and infant death observed suggests that participants in the study had unusually severe fetal anomalies that may have been more likely to have a genetic cause.

Providing prenatal exome on a clinical basis is a challenging scenario; such services require analysis by a multidisciplinary team of perinatal practitioners and laboratory specialists. Another challenge in prenatal exome analysis is that only some genetic disorders give rise to a prenatal phenotype, and the fact that many genes critical to human development have yet to be identified (Vora and Hui 2018). In addition, the difficulty of detailed phenotyping, limited timeframe and genetic counselling of variants of unknown significance (VUS) may add extra challenges to prenatal exome diagnosis (Yates et al. 2017). Therefore, to overcome such challenges, careful selection criteria should be considered for cases of prenatal ES (Lord et al. 2019). These criteria should include a detailed phenotype of the fetus, considering ES as a phenotype-driven test, family medical history, trio-ES over solo-ES, rapid turnaround time, pre and post-test counselling and clinical utility of a prenatal diagnosis.

In prenatal settings where ES is available, we urge the use of trios instead of singletons as this invasive procedure is worth performing at once. De novo and compound heterozygous variants in addition to potential VUS require familial segregation and confirmation, which can be ascertained by trio-ES. Although the average turnaround time of ES testing in this study was 31 days, we believe that up to 15 days turnaround time would be both desirable and achievable. The turnaround time of prenatal ES has to be rapid to provide proper counselling, management of the current pregnancy, and options for future reproduction. The information provided by genetic testing to people has received increased attention. In prenatal settings, a combination of USS and molecular genetics findings has facilitated management of pregnancy. Clinical utility of genetic findings in this cohort has translated to families in the following ways: first, by providing preventive measures to families in category A in subsequent pregnancies through offering prenatal targeted variant testing or Preimplantation Genetic Diagnosis; secondly, by reducing the cost and effort by avoiding unnecessary tests and procedures; and thirdly, by offering the termination of pregnancy for fetuses with poor prognosis according to Saudi law.

The current study supports previous findings that autosomal recessive pathogenic variants are more common in our consanguineous population as compared to outbred populations where de novo variants are the most common cause of fetal malformations (Li et al. 2017). In this cohort, de novo mutations account for around $4 \%$ of cases with fetal abnormalities. Interestingly, no X-linked genes were encountered in this cohort.

Most ciliopathy genes detected in category A (AHI1, CC2D2A, NEK8, TCTN2, TMEM67, TMEM237, and TMEM231) showed multisystem manifestation leading to fetal or perinatal death. In our cohort, most fetuses with loss of function variants in cilia genes showed echogenic enlarged kidneys, encephalocele, skeletal dysplasia and polydactyly phenotypes as reported before, and with anhydramnios or oligohydramnios being common observations in such fetuses (Al-Hamed et al. 2016). The prenatal recognition of a ciliopathy syndrome affecting a fetus is often amenable due to subtle imaging findings in kidneys, brain and extremities (Braun and Hildebrandt 2017).

Although CMA was performed on 67 cases, positive results explaining the prenatal phenotype were found in 8 cases only (12\% of tested cases), which support the prioritisation of performing trio-ES as the initial genetic analysis in consanguineous populations. We recognised that the number of CNVs in this cohort is potentially higher, as many cases were not investigated using CMA. Trio-ES accompanied by CNV analysis is widely used in many genetic laboratories. A NGS-based CNV detection can be performed in parallel with exome sequence analysis and using this approach it is possible to detect a wide range of CNV sizes (Wang et al. 2018). The drawback of this approach is the limitation of short-read NGS for CNV calling in addition to other factors that can impact the ability to detect CNVs such as sample quality, uniformity and high sequencing coverage. 
Despite ES and its combination with CMA where possible, a significant proportion of cases (27\%) remained genetically unsolved. These cases could be further investigated by conventional karyotyping or genome sequencing, which is becoming more widely available in mainstream genetic diagnostics (Turro et al. 2020).

In conclusion, the revolution of NGS has increased our ability to improve feto-maternal medicine diagnostics. Trio-ES guided by prenatal ultrasound (USS) detected molecular defects in around half of consanguineous families with fetal structural anatomic anomalies and a family medical history of congenital anomalies. There was a propensity of multisystem phenotypes with genetic diagnoses in ciliopathy associated diseases. A trio-ES approach to antenatal structural anomalies provides an accurate diagnosis and can be used to predict recurrence rates and to make possible planning for future pregnancies.

\section{Declarations}

\section{Data availability}

All data generated during this study are included in this published article and its supplementary information files.

\section{Conflicts of interest}

The authors have no conflicts of interest to declare.

\section{Funding}

Not applicable

\section{Acknowledgments}

We thank all families who participated in the study. We acknowledge the support of the Saudi Human Genome Program as well as the Saudi Diagnostic Laboratory administration and staff. We thank the sequencing core facility at the Genetics Department at the King Faisal Specialist Hospital and Research Centre for performing Sanger sequencing. The authors declare no conflict of interest. JAS is funded by Kidney Research UK and the Northern Counties Kidney Research Fund.

\section{Authors' contributions}

MHA-H. JAS and FI conceived the study and participated in its design, coordination, drafted and revised the manuscript. WK, RK, MT, MAN, NS and $M M$ participated in the clinical diagnosis of the cases. MHA-H, RR, MA, ZR, ND, KR, JAS and FH participated in exome analysis. AO, WA, AS, RA, LQ, HB, AA, NM and AK carried out all technical aspects of molecular diagnosis. GM, WM, SD, SA, BS, HB, and MA participated in the collection of data of enrolled cases. JAS revised the manuscript. All authors read and approved the final manuscript.

\section{Ethics Declaration}

The study was approved by the Research Advisory Council at King Faisal Specialist Hospital and Research Centre (KFSH\&RC), Riyadh, Saudi Arabia (RAC\# 2211035).

\section{Consent to participate}

Informed consent was obtained from all individual participants included in the study.

\section{Consent for publication}

Not applicable

\section{Code availability}

Not applicable

\section{References}

1. Abu-El-Haija A, Fineman J, Connolly AJ, Murali P, Judge LM, Slavotinek AM (2018) Two patients with FOXF1 mutations with alveolar capillary dysplasia with misalignment of pulmonary veins and other malformations: Two different presentations and outcomes. Am $\mathrm{J}$ Med Genet A 176:2877-2881. doi:10.1002/ajmg.a.40641 
2. Abu-Safieh L, Abboud EB, Alkuraya H, Shamseldin H, Al-Enzi S, Al-Abdi L, Hashem M, Colak D, Jarallah A, Ahmad H, Bobis S, Nemer G, Bitar F, Alkuraya FS (2011) Mutation of IGFBP7 causes upregulation of BRAF/MEK/ERK pathway and familial retinal arterial macroaneurysms. Am J Hum Genet 89:313-319. doi:10.1016/j.ajhg.2011.07.010

3. Al-Hamed MH, Alsahan N, Tulbah M, Kurdi W, Ali W, Sayer JA, Imtiaz F (2020) Fetal Anomalies Associated with Novel Pathogenic Variants in TMEM94. Genes (Basel) 11. doi: 10.3390/genes11090967

4. Al-Hamed MH, Kurdi W, Alsahan N, Alabdullah Z, Abudraz R, Tulbah M, Alnemer M, Khan R, Al-Jurayb H, Alahmed A, Tahir Al, Khalil D, Edwards N, Al Abdulaziz B, Binhumaid FS, Majid S, Faquih T, El-Kalioby M, Abouelhoda M, Altassan N, Monies D, Meyer B, Sayer JA, Albaqumi M (2016) Genetic spectrum of Saudi Arabian patients with antenatal cystic kidney disease and ciliopathy phenotypes using a targeted renal gene panel. J Med Genet 53:338-347. doi:10.1136/jmedgenet-2015-103469

5. AlAbdi L, Alrashseed S, Alsulaiman A, Helaby R, Imtiaz F, Alhamed M, Alkuraya FS (2021) Residual risk for additional recessive diseases in consanguineous couples. Genet Med. doi:10.1038/s41436-021-01289-5

6. Alkuraya FS (2013) Impact of new genomic tools on the practice of clinical genetics in consanguineous populations: the Saudi experience. Clin Genet 84:203-208. doi:10.1111/cge.12131

7. Alsahan N, Alkuraya FS (2020) Confirming TBC1D32-related ciliopathy in humans. Am J Med Genet A. doi:10.1002/ajmg.a.61717

8. American College of O, Gynecologists' Committee on Practice B-O, Committee on G, Society for Maternal-Fetal M (2016) Practice Bulletin No. 162: Prenatal Diagnostic Testing for Genetic Disorders. Obstet Gynecol 127: e108-22. doi: 10.1097/A0G.0000000000001405

9. Bachmann-Gagescu R, Dempsey JC, Phelps IG, O'Roak BJ, Knutzen DM, Rue TC, Ishak GE, Isabella CR, Gorden N, Adkins J, Boyle EA, de Lacy N, O'Day D, Alswaid A, Ramadevi AR, Lingappa L, Lourenço C, Martorell L, Garcia-Cazorla À, Ozyürek H, Haliloğlu G, Tuysuz B, Topçu M, Chance P, Parisi MA, Glass IA, Shendure J, Doherty D (2015) Joubert syndrome: a model for untangling recessive disorders with extreme genetic heterogeneity. J Med Genet 52:514-522. doi:10.1136/jmedgenet-2015-103087

10. Beltrán-Valero de Bernabé D, Currier S, Steinbrecher A, Celli J, van Beusekom E, van der Zwaag B, Kayserili H, Merlini L, Chitayat D, Dobyns WB, Cormand B, Lehesjoki AE, Cruces J, Voit T, Walsh CA, van Bokhoven H, Brunner HG (2002) Mutations in the O-mannosyltransferase gene POMT1 give rise to the severe neuronal migration disorder Walker-Warburg syndrome. Am J Hum Genet 71:1033-1043. doi:10.1086/342975

11. Bergmann C, Fliegauf M, Brüchle NO, Frank V, Olbrich H, Kirschner J, Schermer B, Schmedding I, Kispert A, Kränzlin B, Nürnberg G, Becker C, Grimm T, Girschick G, Lynch SA, Kelehan P, Senderek J, Neuhaus TJ, Stallmach T, Zentgraf H, Nürnberg P, Gretz N, Lo C, Lienkamp S, Schäfer T, Walz G, Benzing T, Zerres K, Omran H (2008) Loss of nephrocystin-3 function can cause embryonic lethality, Meckel-Gruber-like syndrome, situs inversus, and renal-hepatic-pancreatic dysplasia. Am J Hum Genet 82:959-970. doi:10.1016/j.ajhg.2008.02.017

12. Bertoli-Avella AM, Beetz C, Ameziane N, Rocha ME, Guatibonza P, Pereira C, Calvo M, Herrera-Ordonez N, Segura-Castel M, Diego-Alvarez D, Zawada M, Kandaswamy KK, Werber M, Paknia O, Zielske S, Ugrinovski D, Warnack G, Kampe K, lurașcu MI, Cozma C, Vogel F, Alhashem A, Hertecant J, Al-Shamsi AM, Alswaid AF, Eyaid W, Al Mutairi F, Alfares A, Albalwi MA, Alfadhel M, Al-Sannaa NA, Reardon W, Alanay Y, Rolfs A, Bauer $P$ (2021) Successful application of genome sequencing in a diagnostic setting: 1007 index cases from a clinically heterogeneous cohort. Eur J Hum Genet 29:141-153. doi:10.1038/s41431-020-00713-9

13. Best S, Wou K, Vora N, Van der Veyver IB, Wapner R, Chitty LS (2018) Promises, pitfalls and practicalities of prenatal whole exome sequencing. Prenat Diagn 38:10-19. doi:10.1002/pd.5102

14. Bond J, Scott S, Hampshire DJ, Springell K, Corry P, Abramowicz MJ, Mochida GH, Hennekam RC, Maher ER, Fryns JP, Alswaid A, Jafri H, Rashid Y, Mubaidin A, Walsh CA, Roberts E, Woods CG (2003) Protein-truncating mutations in ASPM cause variable reduction in brain size. Am J Hum Genet 73:1170-1177. doi:10.1086/379085

15. Braun DA, Hildebrandt F (2017) Ciliopathies. Cold Spring Harb Perspect Biol 9. doi: 10.1101/cshperspect.a028191

16. Chaki M, Hoefele J, Allen SJ, Ramaswami G, Janssen S, Bergmann C, Heckenlively JR, Otto EA, Hildebrandt F (2011) Genotype-phenotype correlation in 440 patients with NPHP-related ciliopathies. Kidney Int 80:1239-1245. doi:10.1038/ki.2011.284

17. Chen YH, Grigelioniene G, Newton PT, Gullander J, Elfving M, Hammarsjö A, Batkovskyte D, Alsaif HS, Kurdi WIY, Abdulwahab F, Shanmugasundaram V, Devey L, Bacrot S, Brodszki J, Huber C, Hamel B, Gisselsson D, Papadogiannakis N, Jedrycha K, Gürtl-Lackner B, Chagin AS, Nishimura G, Aschenbrenner D, Alkuraya FS, Laurence A, Cormier-Daire V, Uhlig HH (2020) Absence of GP130 cytokine receptor signaling causes extended Stüve-Wiedemann syndrome. J Exp Med 217. doi:10.1084/jem.20191306

18. Dillon OJ, Lunke S, Stark Z, Yeung A, Thorne N, Melbourne Genomics Health A, Gaff C, White SM, Tan TY (2018) Exome sequencing has higher diagnostic yield compared to simulated disease-specific panels in children with suspected monogenic disorders. Eur $\mathrm{J}$ Hum Genet 26:644-651. doi:10.1038/s41431-018-0099-1

19. Frank V, Habbig S, Bartram MP, Eisenberger T, Veenstra-Knol HE, Decker C, Boorsma RA, Göbel H, Nürnberg G, Griessmann A, Franke M, Borgal L, Kohli P, Völker LA, Dötsch J, Nürnberg P, Benzing T, Bolz HJ, Johnson C, Gerkes EH, Schermer B, Bergmann C (2013) Mutations in NEK8 link multiple organ dysplasia with altered Hippo signalling and increased c-MYC expression. Hum Mol Genet 22:2177-2185. doi: $10.1093 / \mathrm{hmg} / \mathrm{ddt} 070$

Page 12/18 
20. Geis T, Rödl T, Topaloğlu H, Balci-Hayta B, Hinreiner S, Müller-Felber W, Schoser B, Mehraein Y, Hübner A, Zirn B, Hoopmann M, Reutter H, Mowat D, Schuierer G, Schara U, Hehr U, Kölbel H (2019) Clinical long-time course, novel mutations and genotype-phenotype correlation in a cohort of 27 families with POMT1-related disorders. Orphanet J Rare Dis 14:179. doi:10.1186/s13023-019-1119-0

21. Geremek M, Dudarewicz L, Obersztyn E, Paczkowska M, Smyk M, Sobecka K, Nowakowska B (2020) Null variants in AGRN cause lethal fetal akinesia deformation sequence. Clin Genet 97:634-638. doi:10.1111/cge.13677

22. Gnanasambandam R, Rivera A, Vandorpe DH, Shmukler BE, Brugnara C, Snyder LM, Andolfo I, lolascon A, Silveira PA, Hamerschlak N, Gottlieb P, Alper SL (2018) Increased Red Cell KCNN4 Activity in Sporadic Hereditary Xerocytosis Associated With Enhanced Single Channel Pressure Sensitivity of PIEZO1 Mutant V598M. Hemasphere 2:e55. doi:10.1097/hs9.0000000000000055

23. Hafsi W, Badri T, Rice AS (2021) Bloom Syndrome. StatPearls. StatPearls Publishing Copyright @ 2021. StatPearls Publishing LLC., Treasure Island (FL)

24. Jelin AC, Vora N (2018) Whole Exome Sequencing: Applications in Prenatal Genetics. Obstet Gynecol Clin North Am 45:69-81. doi:10.1016/j.ogc.2017.10.003

25. Kopanos C, Tsiolkas V, Kouris A, Chapple CE, Albarca Aguilera M, Meyer R, Massouras A (2019) VarSome: the human genomic variant search engine. Bioinformatics 35:1978-1980. doi:10.1093/bioinformatics/bty897

26. Laccone F, Schoner K, Krabichler B, Kluge B, Schwerdtfeger R, Schulze B, Zschocke J, Rehder H (2011) Desbuquois dysplasia type I and fetal hydrops due to novel mutations in the CANT1 gene. Eur J Hum Genet 19:1133-1137. doi:10.1038/ejhg.2011.101

27. Lawson C, Blakemore KJ, Ryan R, Hooper JE, Tsimis M, Jelin A (2020) Sacral protuberance with cleft lip and palate: Prenatal presentation of 3MC syndrome. Am J Med Genet A 182:1812-1814. doi:10.1002/ajmg.a.61624

28. Li J, Oehlert J, Snyder M, Stevenson DK, Shaw GM (2017) Fetal de novo mutations and preterm birth. PLoS Genet 13:e1006689. doi:10.1371/journal.pgen.1006689

29. Liu HY, Zhou L, Zheng MY, Huang J, Wan S, Zhu A, Zhang M, Dong A, Hou L, Li J, Xu H, Lu B, Lu W, Liu P, Lu Y (2019) Diagnostic and clinical utility of whole genome sequencing in a cohort of undiagnosed Chinese families with rare diseases. Sci Rep 9:19365. doi:10.1038/s41598019-55832-1

30. Lord J, McMullan DJ, Eberhardt RY, Rinck G, Hamilton SJ, Quinlan-Jones E, Prigmore E, Keelagher R, Best SK, Carey GK, Mellis R, Robart S, Berry IR, Chandler KE, Cilliers D, Cresswell L, Edwards SL, Gardiner C, Henderson A, Holden ST, Homfray T, Lester T, Lewis RA, Newbury-Ecob R, Prescott K, Quarrell OW, Ramsden SC, Roberts E, Tapon D, Tooley MJ, Vasudevan PC, Weber AP, Wellesley DG, Westwood P, White H, Parker M, Williams D, Jenkins L, Scott RH, Kilby MD, Chitty LS, Hurles ME, Maher ER, Prenatal Assessment of G, Exomes C (2019) Prenatal exome sequencing analysis in fetal structural anomalies detected by ultrasonography (PAGE): a cohort study. Lancet 393: 747-757. doi: 10.1016/S0140-6736(18)31940-8

31. Manolakos E, Vetro A, Garas A, Thomaidis L, Kefalas K, Kitsos G, Ziegler M, Liehr T, Zuffardi O, Papoulidis I (2014) Proximal 10q duplication in a child with severe central hypotonia characterized by array-comparative genomic hybridization: A case report and review of the literature. Exp Ther Med 7:953-957. doi:10.3892/etm.2014.1520

32. Monies D, Abouelhoda M, AlSayed M, Alhassnan Z, Alotaibi M, Kayyali H, Al-Owain M, Shah A, Rahbeeni Z, Al-Muhaizea MA, Alzaidan HI, Cupler E, Bohlega S, Faqeih E, Faden M, Alyounes B, Jaroudi D, Goljan E, Elbardisy H, Akilan A, Albar R, Aldhalaan H, Gulab S, Chedrawi A, Al Saud BK, Kurdi W, Makhseed N, Alqasim T, El Khashab HY, Al-Mousa H, Alhashem A, Kanaan I, Algoufi T, Alsaleem K, Basha TA, Al-Murshedi F, Khan S, Al-Kindy A, Alnemer M, Al-Hajjar S, Alyamani S, Aldhekri H, Al-Mehaidib A, Arnaout R, Dabbagh O, Shagrani M, Broering D, Tulbah M, Alqassmi A, Almugbel M, AlQuaiz M, Alsaman A, Al-Thihli K, Sulaiman RA, Al-Dekhail W, Alsaegh A, Bashiri FA, Qari A, Alhomadi S, Alkuraya H, Alsebayel M, Hamad MH, Szonyi L, Abaalkhail F, Al-Mayouf SM, Almojalli H, Alqadi KS, Elsiesy H, Shuaib TM, Seidahmed MZ, Abosoudah I, Akleh H, AlGhonaium A, Alkharfy TM, Al Mutairi F, Eyaid W, Alshanbary A, Sheikh FR, Alsohaibani Fl, Alsonbul A, Al Tala S, Balkhy S, Bassiouni R, Alenizi AS, Hussein MH, Hassan S, Khalil M, Tabarki B, Alshahwan S, Oshi A, Sabr Y, Alsaadoun S, Salih MA, Mohamed S, Sultana H, Tamim A, El-Haj M, Alshahrani S, Bubshait DK, Alfadhel M et al (2017) The landscape of genetic diseases in Saudi Arabia based on the first 1000 diagnostic panels and exomes. Hum Genet 136:921-939. doi:10.1007/s00439-017-1821-8

33. Mutlu MB, Cetinkaya A, Koc N, Ceylaner G, Erguner B, Aydın H, Karaman S, Demirci O, Goksu K, Karaman A (2016) A novel missense mutation, p.(R102W) in WNT7A causes Al-Awadi Raas-Rothschild syndrome in a fetus. Eur J Med Genet 59:604-606. doi:10.1016/j.ejmg.2016.09.009

34. Nabhan MM, ElKhateeb N, Braun DA, Eun S, Saleem SN, YungGee H, Hildebrandt F, Soliman NA (2017) Cystic kidneys in fetal WalkerWarburg syndrome with POMT2 mutation: Intrafamilial phenotypic variability in four siblings and review of literature. Am J Med Genet A 173:2697-2702. doi:10.1002/ajmg.a.38393

35. Oates C, Taylor $P$ (2016) Helping expectant mothers understand inadequate ultrasound images. Ultrasound 24:142-146. doi:10.1177/1742271X16651901

36. Olinger E, Alawi IA, Al Riyami MS, Salmi IA, Molinari E, Faqeih EA, Al-Hamed MH, Barroso-Gil M, Powell L, Al-Hussaini AA, Rahim KA, Almontashiri NAM, Miles C, Shril S, Hildebrandt F, Consortium GER, Wilson IJ, Sayer JA (2021) A discarded synonymous variant in NPHP3

Page 13/18 
explains nephronophthisis and congenital hepatic fibrosis in several families. Hum Mutat. doi:10.1002/humu.24251

37. Petrovski S, Aggarwal V, Giordano JL, Stosic M, Wou K, Bier L, Spiegel E, Brennan K, Stong N, Jobanputra V, Ren Z, Zhu X, Mebane C, Nahum O, Wang Q, Kamalakaran S, Malone C, Anyane-Yeboa K, Miller R, Levy B, Goldstein DB, Wapner RJ (2019) Whole-exome sequencing in the evaluation of fetal structural anomalies: a prospective cohort study. Lancet 393:758-767. doi:10.1016/S0140-6736(18)32042-7

38. Rafi I, Chitty L (2009) Cell-free fetal DNA and non-invasive prenatal diagnosis. Br J Gen Pract 59:e146-e148. doi:10.3399/bjgp09X420572

39. Reuter MS, Chaturvedi RR, Liston E, Manshaei R, Aul RB, Bowdin S, Cohn I, Curtis M, Dhir P, Hayeems RZ, Hosseini SM, Khan R, Ly LG, Marshall CR, Mertens L, Okello JBA, Pereira SL, Raajkumar A, Seed M, Thiruvahindrapuram B, Scherer SW, Kim RH, Jobling RK (2020) The Cardiac Genome Clinic: implementing genome sequencing in pediatric heart disease. Genet Med 22:1015-1024. doi:10.1038/s41436-0200757-x

40. Riggs ER, Andersen EF, Cherry AM, Kantarci S, Kearney H, Patel A, Raca G, Ritter DI, South ST, Thorland EC, Pineda-Alvarez D, Aradhya S, Martin CL (2020) Technical standards for the interpretation and reporting of constitutional copy-number variants: a joint consensus recommendation of the American College of Medical Genetics and Genomics (ACMG) and the Clinical Genome Resource (ClinGen). Genet Med 22:245-257. doi:10.1038/s41436-019-0686-8

41. Roberts AM, Ware JS, Herman DS, Schafer S, Baksi J, Bick AG, Buchan RJ, Walsh R, John S, Wilkinson S, Mazzarotto F, Felkin LE, Gong S, MacArthur JA, Cunningham F, Flannick J, Gabriel SB, Altshuler DM, Macdonald PS, Heinig M, Keogh AM, Hayward CS, Banner NR, Pennell DJ, O'Regan DP, San TR, de Marvao A, Dawes TJ, Gulati A, Birks EJ, Yacoub MH, Radke M, Gotthardt M, Wilson JG, O'Donnell CJ, Prasad SK, Barton PJ, Fatkin D, Hubner N, Seidman JG, Seidman CE, Cook SA (2015) Integrated allelic, transcriptional, and phenomic dissection of the cardiac effects of titin truncations in health and disease. Sci Transl Med 7:270ra6. doi:10.1126/scitranslmed.3010134

42. Rump P, Letteboer TG, Gille JJ, Torringa MJ, Baerts W, van Gestel JP, Verheij JB, van Essen AJ (2006) Severe complications in a child with achondroplasia and two FGFR3 mutations on the same allele. Am J Med Genet A 140:284-290. doi:10.1002/ajmg.a.31084

43. Salzano E, Raible SE, Kaur M, Wilkens A, Sperti G, Tilton RK, Bettini LR, Rocca A, Cocchi G, Selicorni A, Conlin LK, McEldrew D, Gupta R, Thakur S, Izumi K, Krantz ID (2018) Prenatal profile of Pallister-Killian syndrome: Retrospective analysis of 114 pregnancies, literature review and approach to prenatal diagnosis. Am J Med Genet A 176:2575-2586. doi:10.1002/ajmg.a.40499

44. Saugier-Veber P, Marguet F, Lecoquierre F, Adle-Biassette H, Guimiot F, Cipriani S, Patrier S, Brasseur-Daudruy M, Goldenberg A, Layet V, Capri Y, Gerard M, Frebourg T, Laquerriere A (2017) Hydrocephalus due to multiple ependymal malformations is caused by mutations in the MPDZ gene. Acta Neuropathol Commun 5:36. doi:10.1186/s40478-017-0438-4

45. Schwartz I, Silva LR, Leistner S, Todeschini LA, Burin MG, Pina-Neto JM, Islam RM, Shah GN, Sly WS, Giugliani R (2003) Mucopolysaccharidosis VII: clinical, biochemical and molecular investigation of a Brazilian family. Clin Genet 64:172-175. doi:10.1034/j.1399-0004.2003.00119.x

46. Schwerd T, Twigg SRF, Aschenbrenner D, Manrique S, Miller KA, Taylor IB, Capitani M, McGowan SJ, Sweeney E, Weber A, Chen L, Bowness P, Riordan A, Cant A, Freeman AF, Milner JD, Holland SM, Frede N, Muller M, Schmidt-Arras D, Grimbacher B, Wall SA, Jones EY, Wilkie AOM, Uhlig HH (2017) A biallelic mutation in IL6ST encoding the GP130 co-receptor causes immunodeficiency and craniosynostosis. J Exp Med 214:2547-2562. doi:10.1084/jem.20161810

47. Shaheen R, Al-Salam Z, El-Hattab AW, Alkuraya FS (2016a) The syndrome dysmorphic facies, renal agenesis, ambiguous genitalia, microcephaly, polydactyly and lissencephaly (DREAM-PL): Report of two additional patients. Am J Med Genet A 170:3222-3226. doi:10.1002/ajmg.a.37877

48. Shaheen R, Ansari S, Mardawi EA, Alshammari MJ, Alkuraya FS (2013) Mutations in TMEM231 cause Meckel-Gruber syndrome. J Med Genet 50:160-162. doi:10.1136/jmedgenet-2012-101431

49. Shaheen R, Mark P, Prevost CT, AlKindi A, Alhag A, Estwani F, Al-Sheddi T, Alobeid E, Alenazi MM, Ewida N, Ibrahim N, Hashem M, Abdulwahab F, Bryant EM, Spinelli E, Millichap J, Barnett SS, Kearney HM, Accogli A, Scala M, Capra V, Nigro V, Fu D, Alkuraya FS (2019) Biallelic variants in CTU2 cause DREAM-PL syndrome and impair thiolation of tRNA wobble U34. Hum Mutat 40:2108-2120. doi:10.1002/humu.23870

50. Shaheen R, Patel N, Shamseldin H, Alzahrani F, Al-Yamany R, Ewida AAL, Anazi N, Alnemer S, Elsheikh M, Alfaleh M, Alshammari K, Alhashem M, Alangari A, Salih AA, Kircher MA, Daza M, Ibrahim RM, Wakil N, Alaqeel SM, Altowaijri A, Shendure I, Al-Habib J, Faqieh A, Alkuraya E FS (2016b) Accelerating matchmaking of novel dysmorphology syndromes through clinical and genomic characterization of a large cohort. Genet Med 18:686-695. doi:10.1038/gim.2015.147

51. Shaheen R, Sebai MA, Patel N, Ewida N, Kurdi W, Altweijri I, Sogaty S, Almardawi E, Seidahmed MZ, Alnemri A, Madirevula S, Ibrahim N, Abdulwahab F, Hashem M, Al-Sheddi T, Alomar R, Alobeid E, Sallout B, AlBaqawi B, AlAali W, Ajaji N, Lesmana H, Hopkin RJ, Dupuis L, Mendoza-Londono R, Al Rukban H, Yoon G, Faqeih E, Alkuraya FS (2017) The genetic landscape of familial congenital hydrocephalus. Ann Neurol 81:890-897. doi:10.1002/ana.24964

52. Shaheen R, Szymanska K, Basu B, Patel N, Ewida N, Faqeih E, Al Hashem A, Derar N, Alsharif H, Aldahmesh MA, Alazami AM, Hashem M, Ibrahim N, Abdulwahab FM, Sonbul R, Alkuraya H, Alnemer M, Al Tala S, Al-Husain M, Morsy H, Seidahmed MZ, Meriki N, Al-Owain M, 
AlShahwan S, Tabarki B, Salih MA, Faquih T, El-Kalioby M, Ueffing M, Boldt K, Logan CV, Parry DA, Al Tassan N, Monies D, Megarbane A, Abouelhoda M, Halees A, Johnson CA, Alkuraya FS (2016c) Characterizing the morbid genome of ciliopathies. Genome Biol 17:242. doi:10.1186/s13059-016-1099-5

53. Shamseldin HE, Tulbah M, Kurdi W, Nemer M, Alsahan N, Al Mardawi E, Khalifa O, Hashem A, Kurdi A, Babay Z, Bubshait DK, Ibrahim N, Abdulwahab F, Rahbeeni Z, Hashem M, Alkuraya FS (2015) Identification of embryonic lethal genes in humans by autozygosity mapping and exome sequencing in consanguineous families. Genome Biol 16:116. doi:10.1186/s13059-015-0681-6

54. Srivastava S, Molinari E, Raman S, Sayer JA (2017) Many Genes-One Disease? Genetics of Nephronophthisis (NPHP) and NPHP-Associated Disorders. Front Pediatr 5:287. doi:10.3389/fped.2017.00287

55. Stankiewicz P, Kulkarni S, Dharmadhikari AV, Sampath S, Bhatt SS, Shaikh TH, Xia Z, Pursley AN, Cooper ML, Shinawi M, Paciorkowski AR, Grange DK, Noetzel MJ, Saunders S, Simons P, Summar M, Lee B, Scaglia F, Fellmann F, Martinet D, Beckmann JS, Asamoah A, Platky K, Sparks S, Martin AS, Madan-Khetarpal S, Hoover J, Medne L, Bonnemann CG, Moeschler JB, Vallee SE, Parikh S, Irwin P, Dalzell VP, Smith WE, Banks VC, Flannery DB, Lovell CM, Bellus GA, Golden-Grant K, Gorski JL, Kussmann JL, McGregor TL, Hamid R, Pfotenhauer J, Ballif BC, Shaw CA, Kang SH, Bacino CA, Patel A, Rosenfeld JA, Cheung SW, Shaffer LG (2012) Recurrent deletions and reciprocal duplications of 10q11.21q11.23 including CHAT and SLC18A3 are likely mediated by complex low-copy repeats. Hum Mutat 33:165-179. doi:10.1002/humu.21614

56. Stankiewicz P, Sen P, Bhatt SS, Storer M, Xia Z, Bejjani BA, Ou Z, Wiszniewska J, Driscoll DJ, Maisenbacher MK, Bolivar J, Bauer M, Zackai EH, McDonald-McGinn D, Nowaczyk MM, Murray M, Hustead V, Mascotti K, Schultz R, Hallam L, McRae D, Nicholson AG, Newbury R, Durham-O'Donnell J, Knight G, Kini U, Shaikh TH, Martin V, Tyreman M, Simonic I, Willatt L, Paterson J, Mehta S, Rajan D, Fitzgerald T, Gribble S, Prigmore E, Patel A, Shaffer LG, Carter NP, Cheung SW, Langston C, Shaw-Smith C (2009) Genomic and genic deletions of the FOX gene cluster on 16q24.1 and inactivating mutations of FOXF1 cause alveolar capillary dysplasia and other malformations. Am J Hum Genet 84:780-791. doi:10.1016/j.ajhg.2009.05.005

57. Sun L, Tong H, Wang H, Yue Z, Liu T, Lin H, Li J, Wang C (2016) High mutation rate of NPHP3 in 18 Chinese infantile nephronophthisis patients. Nephrology (Carlton) 21:209-216. doi:10.1111/nep.12563

58. Talkowski ME, Ordulu Z, Pillalamarri V, Benson CB, Blumenthal I, Connolly S, Hanscom C, Hussain N, Pereira S, Picker J, Rosenfeld JA, Shaffer LG, Wilkins-Haug LE, Gusella JF, Morton CC (2012) Clinical diagnosis by whole-genome sequencing of a prenatal sample. N Engl J Med 367:2226-2232. doi:10.1056/NEJMoa1208594

59. Tallila J, Jakkula E, Peltonen L, Salonen R, Kestilä M (2008) Identification of CC2D2A as a Meckel syndrome gene adds an important piece to the ciliopathy puzzle. Am J Hum Genet 82:1361-1367. doi:10.1016/j.ajhg.2008.05.004

60. Tamary H, Dgany O (1993) Alpha-Thalassemia. In: Adam MP, Ardinger HH, Pagon RA, Wallace SE, Bean LJH, Mirzaa G, Amemiya A (eds) GeneReviews(®). University of Washington, Seattle Copyright @ $1993-2021$, University of Washington, Seattle. GeneReviews is a registered trademark of the University of Washington, Seattle. All rights reserved., Seattle (WA)

61. Tartaglia M, Cordeddu V, Chang H, Shaw A, Kalidas K, Crosby A, Patton MA, Sorcini M, van der Burgt I, Jeffery S, Gelb BD (2004) Paternal germline origin and sex-ratio distortion in transmission of PTPN11 mutations in Noonan syndrome. Am J Hum Genet 75:492-497. doi:10.1086/423493

62. Toriyama M, Lee C, Taylor SP, Duran I, Cohn DH, Bruel AL, Tabler JM, Drew K, Kelly MR, Kim S, Park TJ, Braun DA, Pierquin G, Biver A, Wagner K, Malfroot A, Panigrahi I, Franco B, Al-Lami HA, Yeung Y, Choi YJ, Duffourd Y, Faivre L, Rivière JB, Chen J, Liu KJ, Marcotte EM, Hildebrandt F, Thauvin-Robinet C, Krakow D, Jackson PK, Wallingford JB (2016) The ciliopathy-associated CPLANE proteins direct basal body recruitment of intraflagellar transport machinery. Nat Genet 48:648-656. doi:10.1038/ng.3558

63. Tory K, Rousset-Rouvière C, Gubler MC, Morinière V, Pawtowski A, Becker C, Guyot C, Gié S, Frishberg Y, Nivet H, Deschênes G, Cochat P, Gagnadoux MF, Saunier S, Antignac C, Salomon R (2009) Mutations of NPHP2 and NPHP3 in infantile nephronophthisis. Kidney Int 75:839-847. doi:10.1038/ki.2008.662

64. Toydemir RM, Rutherford A, Whitby FG, Jorde LB, Carey JC, Bamshad MJ (2006) Mutations in embryonic myosin heavy chain (MYH3) cause Freeman-Sheldon syndrome and Sheldon-Hall syndrome. Nat Genet 38:561-565. doi:10.1038/ng1775

65. Turro E, Astle WJ, Megy K, Gräf S, Greene D, Shamardina O, Allen HL, Sanchis-Juan A, Frontini M, Thys C, Stephens J, Mapeta R, Burren OS, Downes K, Haimel M, Tuna S, Deevi SVV, Aitman TJ, Bennett DL, Calleja P, Carss K, Caulfield MJ, Chinnery PF, Dixon PH, Gale DP, James R, Koziell A, Laffan MA, Levine AP, Maher ER, Markus HS, Morales J, Morrell NW, Mumford AD, Ormondroyd E, Rankin S, Rendon A, Richardson S, Roberts I, Roy NBA, Saleem MA, Smith KGC, Stark H, Tan RYY, Themistocleous AC, Thrasher AJ, Watkins H, Webster AR, Wilkins MR, Williamson C, Whitworth J, Humphray S, Bentley DR, Kingston N, Walker N, Bradley JR, Ashford S, Penkett CJ, Freson K, Stirrups KE, Raymond FL, Ouwehand WH (2020) Whole-genome sequencing of patients with rare diseases in a national health system. Nature 583:96102. doi:10.1038/s41586-020-2434-2

66. Vahidnezhad H, Youssefian L, Saeidian AH, Mahmoudi H, Touati A, Abiri M, Kajbafzadeh AM, Aristodemou S, Liu L, McGrath JA, Ertel A, Londin E, Kariminejad A, Zeinali S, Fortina P, Uitto J (2018) Recessive mutation in tetraspanin CD151 causes Kindler syndrome-like epidermolysis bullosa with multi-systemic manifestations including nephropathy. Matrix Biol 66:22-33. doi:10.1016/j.matbio.2017.11.003

Page 15/18 
67. Vivante A, Hwang DY, Kohl S, Chen J, Shril S, Schulz J, van der Ven A, Daouk G, Soliman NA, Kumar AS, Senguttuvan P, Kehinde EO, Tasic V, Hildebrandt F (2017) Exome Sequencing Discerns Syndromes in Patients from Consanguineous Families with Congenital Anomalies of the Kidneys and Urinary Tract. J Am Soc Nephrol 28:69-75. doi:10.1681/asn.2015080962

68. Vora NL, Hui L (2018) Next-generation sequencing and prenatal 'omics: advanced diagnostics and new insights into human development. Genet Med 20:791-799. doi:10.1038/s41436-018-0087-4

69. Vora NL, Powell B, Brandt A, Strande N, Hardisty E, Gilmore K, Foreman AKM, Wilhelmsen K, Bizon C, Reilly J, Owen P, Powell CM, Skinner D, Rini C, Lyerly AD, Boggess KA, Weck K, Berg JS, Evans JP (2017) Prenatal exome sequencing in anomalous fetuses: new opportunities and challenges. Genet Med 19:1207-1216. doi:10.1038/gim.2017.33

70. Wang J, Chen L, Zhou C, Wang L, Xie H, Xiao Y, Zhu H, Hu T, Zhang Z, Zhu Q, Liu Z, Liu S, Wang H, Xu M, Ren Z, Yu F, Cram DS, Liu H (2018) Prospective chromosome analysis of 3429 amniocentesis samples in China using copy number variation sequencing. Am $\mathrm{J}$ Obstet Gynecol 219: 287 e1-287 e18. doi: 10.1016/j.ajog.2018.05.030

71. Wapner RJ, Martin CL, Levy B, Ballif BC, Eng CM, Zachary JM, Savage M, Platt LD, Saltzman D, Grobman WA, Klugman S, Scholl T, Simpson JL, McCall K, Aggarwal VS, Bunke B, Nahum O, Patel A, Lamb AN, Thom EA, Beaudet AL, Ledbetter DH, Shaffer LG, Jackson L (2012) Chromosomal microarray versus karyotyping for prenatal diagnosis. N Engl J Med 367:2175-2184. doi:10.1056/NEJMoa1203382

72. Wojcik MH, Schwartz TS, Thiele KE, Paterson H, Stadelmaier R, Mullen TE, VanNoy GE, Genetti CA, Madden JA, Gubbels CS, Yu TW, Tan WH, Agrawal PB (2019) Infant mortality: the contribution of genetic disorders. J Perinatol 39:1611-1619. doi:10.1038/s41372-019-0451-5

73. Yates CL, Monaghan KG, Copenheaver D, Retterer K, Scuffins J, Kucera CR, Friedman B, Richard G, Juusola J (2017) Whole-exome sequencing on deceased fetuses with ultrasound anomalies: expanding our knowledge of genetic disease during fetal development. Genet Med 19:1171-1178. doi:10.1038/gim.2017.31

\section{Tables}

Due to technical limitations, Table 2 and 3 are only available as a download in the Supplemental Files section.

\section{Figures}




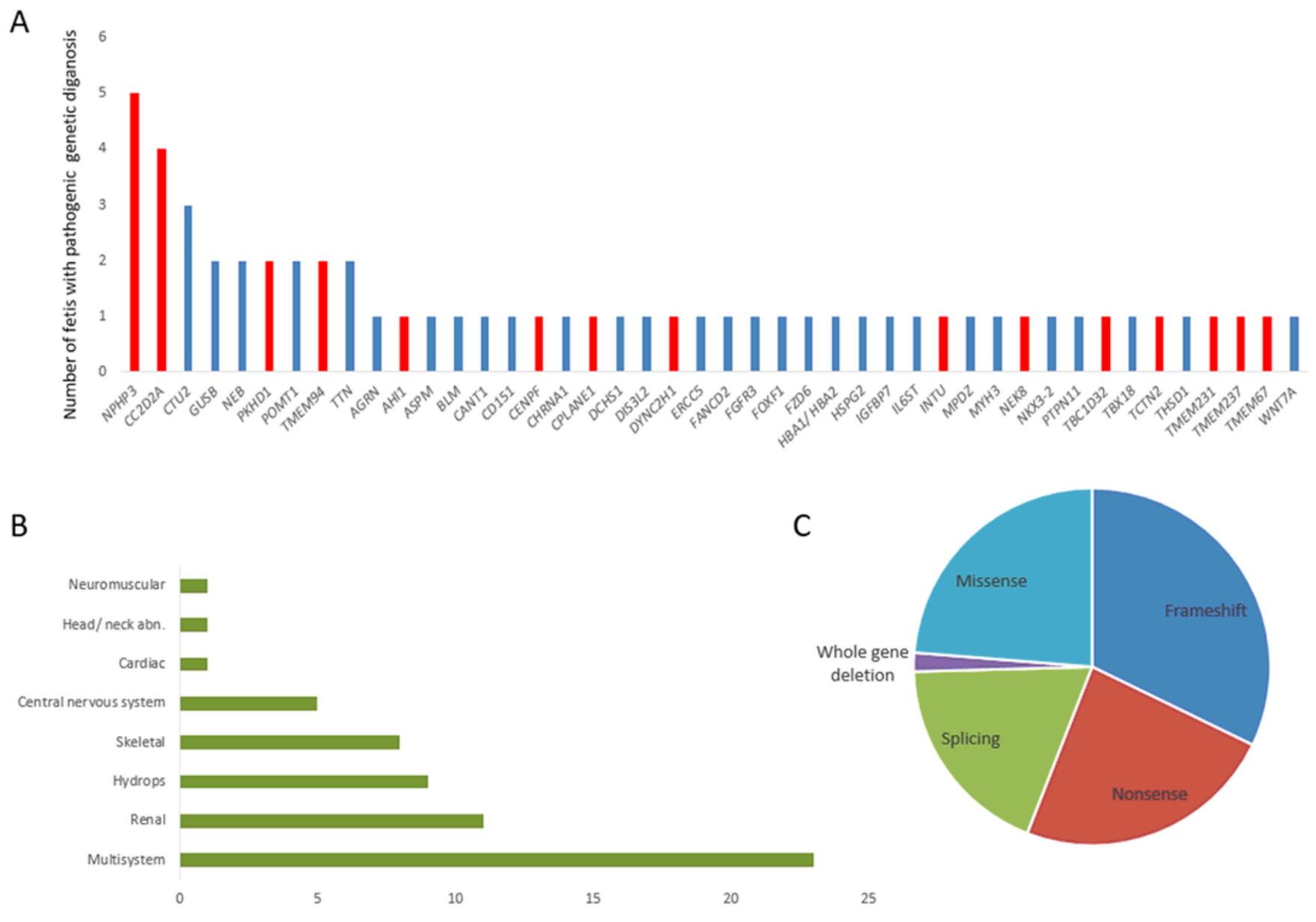

\section{Figure 1}

Molecular genetic findings following exome sequencing and clinical features of the cohort overview of the cohort A. Number of cases for each gene where a molecular genetic diagnosis (pathogenic/likely pathogenic) was made. Cases with variants in known ciliopathy gene are shown in red. B. Overview of fetal phenotypes in cases solved by whole exome sequencing C. Type of mutation identified by whole exome sequencing 


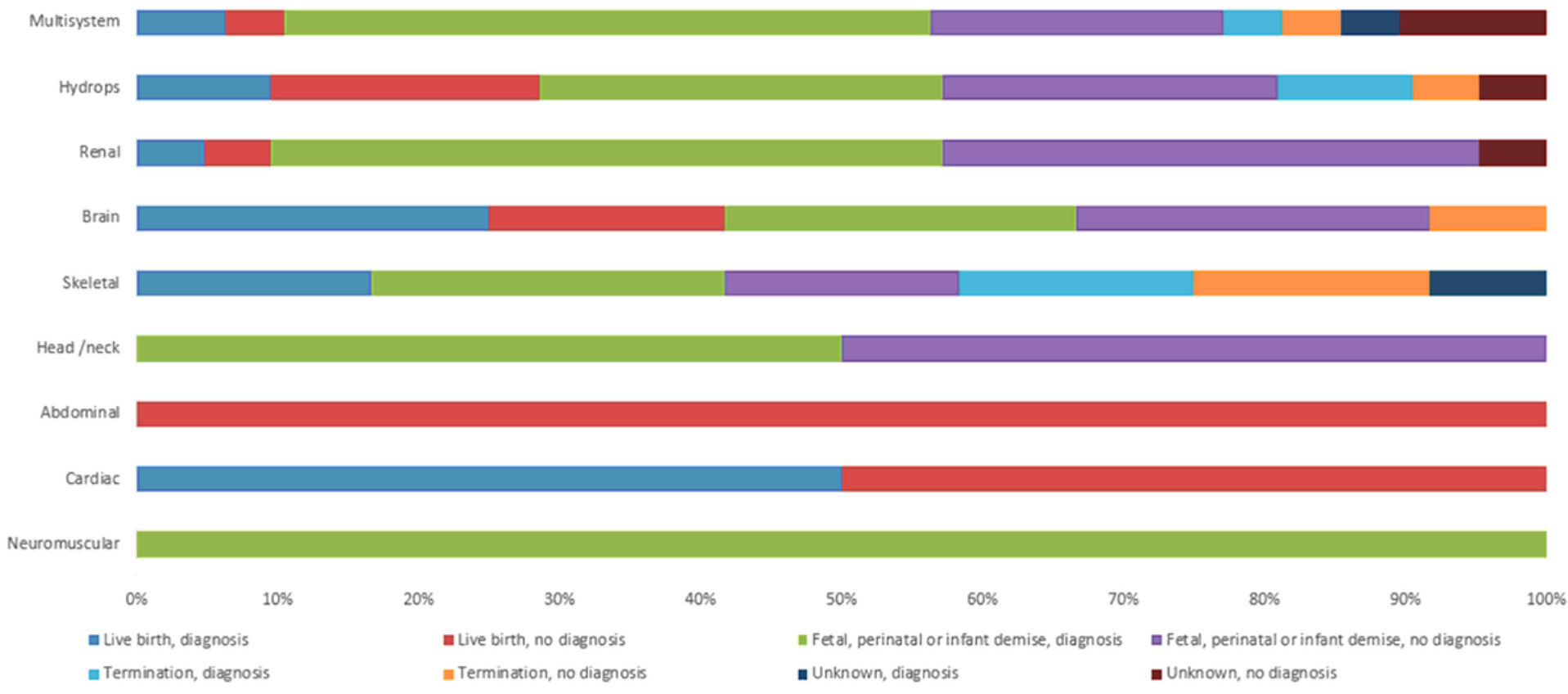

Figure 2

Pregnancy outcomes associated with different fetal structural anomalies 48 fetuses had multisystem anomalies, 21 fetuses had hydrops, 21 fetuses had renal anomalies, 12 fetuses had brain anomalies, 12 fetuses had skeletal anomalies, 2 fetuses had head /neck anomalies, 1 fetus had abdominal anomalies, 1 fetus had cardiac anomalies and 1 fetus had neuromuscular anomalies

\section{Supplementary Files}

This is a list of supplementary files associated with this preprint. Click to download.

- Table2and3.docx

- Figures1.pdf

- Tables1.pdf 